\title{
Effect of Supervision on the Actions of Implementing Nurses in the Implementation of Patient Safety at PTPN IV Kebun Laras Hospital, Simalungun Regency
}

\author{
Era Zana Nisa ${ }^{1}$, Destanul Aulia ${ }^{2}$, Siti Saidah Nasution ${ }^{3}$ \\ ${ }^{1,2,3}$ Universitas Sumatera Utara, Indonesia \\ Corresponding Author: Era Zana Nisa
}

\begin{abstract}
The goal of patient safety is one of the requirements that must be applied to the patient safety program in all hospitals. The implementation of patient safety programs is influenced by behavioral factors, namely the actions of nurses. The implementation of patient safety goals at PTPN IV Kebun Laras Hospital, Simalungun Regency is still not maximally implemented, seen from the actions of nurses, namely there are still incidents that endanger patients (KTD and KNC), and not all nurses behave in accordance with SOPs in implementing patient safety goals. The research used observational analytic method with cross sectional design. The samples were 62 nurses. The results showed that supervision variable had an effect on the actions of implementing nurses in the implementation of patient safety at PTPN IV Kebun Laras Hospital, Simalungun Regency.
\end{abstract}

Keywords: Supervision, Nurses, Patient Safety

\section{INTRODUCTION}

Patient safety is always a top concern for all health workers, especially administrators, doctors, nurses, health professionals, and others. They are directly or indirectly involved in the provision of patient health care in various areas of health care settings. They have a great responsibility to ensure compliance with patient safety goals. This situation requires good knowledge of patient safety in health care settings to ensure patients are safe at all times. To realize this awareness, the WHO patient safety target program was prepared. Patient safety goals become a reference and guideline for hospital accreditation agencies in assessing the performance of health workers in implementing patient safety. The target on patient safety is part of the 2012 version of the accreditation standard that must be implemented in all health services set by the Hospital Accreditation Committee (KARS) by following IPSG guidelines. The guidelines for international patient safety goals (IPSG) are targeted programs on patient safety that are followed and implemented in Indonesia, this program in the practice of care and nursing services is very important to be implemented (Ristekdikti, 2018).

According to Priyoto and Widyastuti (2014) nurses are professions that carry out nursing actions with high dedication in providing simple to complex care to patients, both individuals, groups and families. Services are provided to patients who are sick or healthy. In the hospital, nurses for 24 hours always monitor and record the progress of the patient's condition. The actions or roles of nurses in institutions to improve patient safety programs are by maintaining professional quality, carrying out credentials, maintaining professional ethics and discipline as regulated in Minister of Health Regulation Number 49 of 2014 concerning 
Hospital Nursing Committees (Haryati et al, 2019). Meanwhile, the actions of implementing nurses in improving patient safety, such as mentioning patients where, communicating with SBAR, carrying out efforts to break the chain of infection by maintaining hand hygiene, using personal protective equipment, using aseptic techniques, handling used tools, waste sharp object handling. For patient safety nurses, it is not only a guideline that must be carried out but is a code of ethics for nurses that must be carried out by nurses in carrying out or providing nursing care safely in accordance with the competencies obtained. Although it has been stated in the code of ethics that patient safety must be carried out by nurses, there are still violations or patient safety accidents that occur caused by health workers, one of which is a nurse in health services or hospitals, based on data obtained from the KKP-RS reports, nurses comply with The highest order of $58.4 \%$ among other health care workers in carrying out health care or nursing care is that there are still incidents that occur against security.

Several violations from the results of research on patient safety incidents are the results of research conducted by Yudhawati and Listiowati (2013) that the cause of violations of patient safety incidents in identifying patients is $46 \%$. The results of research by Cheragi et al (2013) show that one of the targets for patient safety, namely errors in drug administration is $64.55 \%$. Based on data from the Ministry of Health of the Republic of Indonesia in 2011 the incidence of patient safety violations committed by nurses was found to be $28.3 \%$.

Nursing service supervision is the supervision, guidance or any assistance provided by the leader or person in charge to nurses where the purpose of this activity is to maximize the performance of nurses and other staff in the achievement of a program that has been implemented. Supervision activities like this are support and opportunities for nurses to develop their expertise in providing nursing care actions, so nurses can optimize all safe nursing care actions in implementing patient safety goals and can provide quality in providing the best health services (Suyanto in Sudarta, 2019).

From the results of Aeni WN's research (2016) supervision has a significant influence in the implementation of patient safety goals applied by nurses. Research conducted by Pambudi et al (2018) states that supervision is influential in carrying out patient safety goals by nurses in carrying out their duties and that supervision from superiors or leaders (supervisors) is very influential and more obedient in implementing patient safety goals, where the research conducted at Panti Waluya Hospital Malang has not run optimally so nurses need supervision from superiors to be able to implement their duties in implementing patient safety goals properly.

PTPN IV Kebun Laras Hospital, located in Simalungun Regency, is a class C hospital that has carried out the Hospital Accreditation process which has the obligation to carry out patient safety. This hospital has 100 beds where it has 23 doctors consisting of 7 general practitioners, 15 specialist doctors and 1 dentist and 115 nurses, with the most characteristic nurses being 17-25 years old. is 45 percent with female sex 77.5 percent, D-III education is 65 percent, married 80 percent, and the length of work in $<5$ years is 40 percent. The bed occupancy rate (BOR) in 2018 was 66.79 percent. The 2018 length of stay (LOS) is 4.88 days.

Based on nosocomial infection data obtained from infection prevention control nurse (IPCN) under the infection control prevention (PPI) committee, in 2018 in the Inpatient Room of PTPN IV Hospital Laras regarding the number of incidents of nosocomial infections, namely the number of cases of urinary tract infections $(0,13 \%)$, infection in the operating area $(0.08 \%)$, primary bloodstream infection $(0 \%)$, ventilator infection associated pneumonia $(0 \%)$, while phlebitis infection $(3.34 \%)$ had not met the predetermined standards. in the 
Minimum Hospital Service, which is less than or equal to $1.5 \%$. Then in February 2018 there was 1 incident of Unexpected Events, namely the patient went to the bathroom without anyone's help using a wheelchair then suddenly the patient was unconscious in the bathroom, then in May and June there were 2 incidents of the patient falling, namely falling in the bathroom and fell out of bed due to not being accompanied by a nurse. In July 2018 there was 1 incident of Unexpected Incidence, namely after the patient was performed for the TAH operation, after the 54th day the surgical wound was still wet, monitored until the 8th day but was still wet, where the hospital standard achievement for unexpected events was 0 cases or incidents (PTPN IV Kebun Laras Hospital, 2018).

Based on a preliminary survey and observations conducted at the PTPN IV Kebun Laras Hospital, from 10 patients who were in several inpatient rooms at the hospital, it was found that there was 1 person who had experienced contraindications, namely edema and nausea and vomiting with drugs given by nurses. and the nurse did not explain the procedure in administering the drug, and was not given a bracelet or red sticker indicating the patient was allergic to the drug, as well as ineffective nurse communication. The 10 nurses in implementing the SKP, there were 5 nurses who only mentioned the patient's name, 2 nurses forgot to ask for confirmation of the DPJP doctor's readback when the room visits was present, 7 nurses only carried out the principle of washing hands with five moments, the nurse only took the action of washing hands when they finished giving nursing actions, and there are 6 nurses who do not monitor patients at risk of falling so that the patient falls.

According to the head of the nursing department, from the results of interviews regarding the application of patient safety goals that affect nurses to implement the program depending on the nurses' lack of knowledge about the program, because not all nurses have attended training, socialization and training, then the attitude of the nurses in responding to the program so that it is still of course, there are some nurses who take actions that are not in accordance with the patient safety program that has been obtained, such as there are still nurses who do not mention the patient's name, nurses do not use communication effectively, errors in administering drugs, not carrying out the principle of washing hands properly, and there are still Nurses do not monitor patients at high risk of falling. Then the support or motivation from outside, namely other people where there is supervision from the leadership, and the quality improvement and patient safety team also influences nurses in implementing patient safety.

According to the room nurse from the interview, she said that the supervision in the room was carried out simultaneously during the exchange of office hours with the head of the room and only in the form of observation. If in carrying out patient safety goals there are mistakes made by nurses, the head of the room only observes and reminds them, there is no scheduled supervision from the hospital. There was no guidance or discussion on scheduled patient safety goals so I wanted to do research on the effect of supervision on the actions of implementing nurses in implementing patient safety at PTPN IV Kebun Laras Hospital, Simalungun Regency.

\section{RESEARCH METHODS}

The research used observational analytic method with cross sectional design. This research was conducted at the PTPN IV Simalungun Regency Hospital. The time of the research was carried out in November 2019 until completion.

The populations in this study were 62 nurses who served in the Inpatient Installation at PTPN IV Kebun Laras Hospital, Simalungun Regency, consisting of VIP inpatient nurses, ICU, Anggrek, Bougenvile, Cempaka, Mawar, Dahlia, Flamboyan, Anyelir, and Melati. The 
sample that will be used in this research is 62 respondents.

The primary data collection method was obtained through the results of a questionnaire on 62 nurses in the inpatient room at PTPN IV Kebun Laras Hospital with the aim of obtaining quantitative data on the supervision of nurses' actions in implementing patient safety goals. Secondary data is data that is indirectly obtained from the source, but through a second party. In this case the researcher uses data obtained from the Human Resources section, improving the quality of patient safety, medical records and other data related to the application of patient safety goals.

The data analysis methods used include univariate analysis, bivariate analysis, and multivariate analysis to see how big the relationship between the independent and dependent variables is.

\section{RESULT AND DISCUSSION \\ Research Location Overview}

PTPN IV Kebun Laras Hospital, located in Simalungun Regency, is a class C hospital that has carried out the hospital accreditation process, given the status of passing hospital accreditation, which has the obligation to implement patient safety in all service areas.

PTPN IV Kebun Laras Hospital has VIP class facilities with 2 beds, class I facilities (Anggrek Room) with 11 beds, class II facilities (Bougenville, Cempaka, Mawar Room) with 35 beds, class III facilities (Dahlia, Flamboyan Room) with 42 beds, Children's Room (carnation) facilities with 12 beds, Maternity Room (Melati) with 8 beds, and ICU with 4 beds.

Based on data from health workers at PTPN IV Kebun Laras Hospital, it can be seen that the highest number of health workers is nurses, namely 115 people, has 23 doctors consisting of 7 general practitioners, 15 specialists and 1 dentist. while for other support staff, there are 115 nurses, 33 medical supports, and 100 bed facilities.
Based on the data and improvement of the quality of patient safety in the inpatient room of the PTPN IV Kebun Laras Hospital regarding the incidence rate of phlebitis with an achievement of $3.34 \%$ where the hospital standard was $\leq 1.5 \%$, the incidence of unexpected incidents was February 2 cases, and the patient fell 2 cases, where the hospital standard is 0 cases. From the observations of 10 patients, it was found that 1 person or patient had experienced contraindications, namely odem and nausea and vomiting with the medicine given by the nurse. The nurse did not explain the procedure in administering the drug, was not given a bracelet or red sticker which indicated the patient was allergic to the drug and the nurse's communication was less effective. From the observations of 10 nurses, there were 5 nurses who only mentioned the patient's name, 2 nurses forgot to ask for confirmation of the DPJP doctor's readback when attending the room visit, 7 nurses only carried out the principle of washing hands with five moments, and 6 nurses who did not monitor patients at risk of falling so they were found patient falls.

\section{Multiple Logistic Regression Test}

Table 1: Multiple Logistic Regression Test

\begin{tabular}{|c|c|c|c|c|c|}
\hline Variable & B & p value & Exp (B) & \multicolumn{2}{|c|}{$95 \%$ CI } \\
\cline { 5 - 6 } & & & & Lower & Upper \\
\hline Supervision & 1.055 & 0.057 & 2.872 & 0.969 & 8.508 \\
\hline Constant & -0.767 & 0.022 & 0.464 & & \\
\hline \multicolumn{6}{c}{ p Hosmer and Lemeshow Test $=0.998$} \\
Classification table 64.5 \\
AUC $=0.618$
\end{tabular}

Based on Table 1, the results of the multiple logistic regression test obtained the final result that supervision has $\mathrm{p}=0.057$ Exp (B) of 2.872, meaning that if the implementing nurse has poor supervision, it is possible that the nurse performs nursing actions that are not good in implementing patient safety times compared to the nurse who has good supervision.

Furthermore, the results of above are entered into the multiple logistic regression equation model as follows: 


$$
\begin{aligned}
& \mathrm{p}(\mathrm{x})=\frac{1}{1+\mathrm{e}^{-(\mathrm{a}+\mathrm{b} 1 \mathrm{x} 1+\mathrm{b} 2 \mathrm{x} 2+\mathrm{b} 3 \times 3+\ldots .+\mathrm{bk} x \mathrm{k})}} \\
& \mathrm{p}(\mathrm{x})=\frac{1}{1+\mathrm{e}^{-(-0,767+(1,055 \mathrm{x} 1)}} \\
& \mathrm{p}(\mathrm{x})=\frac{1}{1+\mathrm{e}^{-(0,288)}} \\
& \mathrm{P}(\mathrm{x})=0,57
\end{aligned}
$$

Based on the results of the above equation, it is known that poor supervision has the opportunity to perform poor nurse actions in the application of patient safety with a probability of 0.57 or 57 percent. In other languages, it can be stated that the probability of implementing nurses doing bad nurse actions in the application of patient safety which is influenced by supervision is $57 \%$ and the remaining $43 \%$ is due to other factors not explained in this model.

According to the theory of Suarli and Bahtiar (2012) supervision must be carried out with a regular frequency. Supervision that is carried out only once can be said to be not good supervision, because the organization/environment is always evolving. Therefore, so that the organization can always keep abreast of various developments and changes, various adjustments need to be made. Supervision can help with this adjustment, namely through increasing the knowledge and skills of subordinates. There are no definite guidelines on how many times supervision should be carried out. Supervision usually depends on the degree of difficulty of the work being carried out, as well as the nature of the adjustments to be made. If the degree of difficulty is high and the nature of the adjustment is basic, more frequent supervision should be exercised.

In line with research conducted by researchers at PTPN IV Kebun Laras Hospital, Simalungun Regency, from the results of Aeni WN's research (2016) supervision has a significant influence in the implementation of patient safety goals applied by nurses. Research conducted by Pambudi et al (2018) shows that supervision is influential in carrying out patient safety goals by nurses in carrying out their duties and the existence of supervision from superiors or leaders (supervisors) is very influential and more obedient in implementing patient safety goals.

Supervision has an effect on the actions of implementing nurses in implementing patient safety at PTPN IV Kebun Laras Hospital, Simalungun Regency. If seen in the univariate analysis, it can be seen that this is influenced by good normative supervision (establishing relationships and trust), formative (selfreflection), and restorative (support) which means the implementation of supervision in the hospital. The barrel is good so that it supports the performance of nurses. The statement of good supervision is based on the recognition of the respondent who stated that the supervisor had never acted wisely during the supervision because the supervisor always acted and never ignored if an incident or accident occurred when the nurse was taking nursing action and immediately discussed the problem with the party involved related to follow-up, supervisors always assist the nurse in carrying out patient safety goals, namely the supervisor helps the nurse in improving patient identification, increasing effective communication, drug safety that must be watched out for, reducing the risk of infection and falls. Supervisors always help if the executive nurse finds it difficult to carry out nursing actions in carrying out patient safety goals. A supervisor or head of the room must always schedule guidance, direction, motivation, and evaluation activities properly so that nurses can optimally feel the role and function of supervision and do not feel pressured to implement patient safety goals during supervision. So it can be concluded that the actions of nurses in completing their duties and obligations basically must be carried out with good supervision. Supervision must be 
Era Zana Nisa et.al. Effect of supervision on the actions of implementing nurses in the implementation of patient safety at PTPN IV Kebun Laras Hospital, Simalungun Regency

a special concern from the management, considering that nurses are the most important part in implementing patient safety goals.

\section{CONCLUSION AND SUGGESTION}

The results showed that supervision variable had an effect on the actions of implementing nurses in the implementation of patient safety at PTPN IV Kebun Laras Hospital, Simalungun Regencyl.

It is recommended for PTPN IV Kebun Laras Hospital, Simalungun Regency to improve the quality of hospital patient safety. PTPN IV Kebun Laras Hospital, Simalungun Regency by holding training or seminars as well as regular and continuous socialization regarding patient safety. Make a program or policy for the development of professional nurses by implementing a system of punishment and reward for nurses in accordance with their performance in implementing patient safety goals properly. Monitoring from the executive nurse supervisor or head of the room periodically by providing scheduled guidance and evaluation so that nurses do not feel burdened in implementing SKP in nursing care services and management should provide adequate facilities in implementing patient safety goals, such as patient wristbands that are always available, and also surgery safety checklist (SSCL) sheet, handscrub in each patient's room and nurse station which has policies and routines related to this.

\section{Acknowledgement}

The author thanks the Head of PT. Prima Medica Nusantara Medan as the Head Office who has allowed to conduct research at the PTPN IV Kebun Laras Hospital, Simalungun Regency, the Head of the PTPN IV Kebun Laras Hospital, Simalungun Regency, who has allowed to conduct research, all nurses who assist the author in research, and all Lecturers at the Faculty of Public Health, Universitas Sumatera Utara for their time and support in completing this research.

\section{Statement}

The author declares that this article is an original work and has never been published.

\section{Author's Contribution}

Author 1: Research concept and design, prepare research proposal, collect data, analyze data, and write manuscript

Author 2: Concept and research design, supervised the research process, was actively involved in data analysis, reviewed manuscript and final edited.

Author 3: Concept and research design, supervised the research process, was actively involved in data analysis, reviewed manuscript and final edited.

\section{Conflict of Interest: None}

\section{Source of Funding: None}

\section{Ethical Approval: Approved}

\section{REFERENCES}

1. Aeni, W. N. (2016). Faktor Pendukung dan Penghambat Pelaksanaan Supervisi untuk Meningkatkan Kepatuhan Perawat dalam Menerapkan SPO Pemasangan Infus di RSUD Indramayu. Tesis. Universitas Diponegoro. Accessed from http://eprints.undip.ac.id/49422/1.

2. Cheragi, Mohammad Ali, Ghadinan, Fatenah, Salsali, \& Mahvash. (2013). Nursing Professionalism: An Evolutionary Concept Analysis. Iranian Journal of Nursing and Midwifery Research, 19(1): 110.

3. Haryati, S.,Yetti, K., Afriani, T., \& Handiyani, H. (2019). Manajemen Risiko bagi Manajer Keperawatan dalam Meningkakan Mutu dan Keselamatan Pasien. Edisi Kesatu. Depok: Rajawali Pers.

4. Pambudi, Y. D. W., Sutriningsih, A., \& Yasin, D. D. F. (2018). Faktor-Faktor Yang Mempengaruhi Perawat dalam Penerapan 6 SKP (Sasaran Keselamatan Pasien) Pada Akreditasi JCI (Joint Commission International) di Ruang Rawat Inap Rumah Sakit Panti Waluya Malang. Nursing News: Jurnal Ilmiah Mahasiswa Keperawatan, 3(1). Accessed from https://publikasi.unitri.ac.id/index.php. 
Era Zana Nisa et.al. Effect of supervision on the actions of implementing nurses in the implementation of patient safety at PTPN IV Kebun Laras Hospital, Simalungun Regency

5. Priyoto \& Widyastuti, T. (2014). Kebutuhan Dasar Keselamatan Pasien. Yogyakarta: Graha Ilmu.

6. PTPN IV Kebun Laras Hospital. (2018). Report on Quality Improvement and Patient Safety at PTPN IV Kebun Laras Hospital.

7. Ristekdikti. (2018). Laporan Peningkatan Mutu dan Keselamatan Pasien RS PTPN IV Kebun Laras.

8. Suarli, S., \& Bahtiar, Y. (2012). Manajemen Keperawatan dengan Pendekatan Praktis. Jakarta: Erlangga.

9. Sudarta, I W. (2019). Manajemen Keperawatan: Penerapan Teori Model dalam Pelayanan Keperawatan. Sleman: Gosyen Publishing.

10. Yudhawati \& Listiowati. (2013). Evaluasi Penerapan Identifikasi Pasien di RSI Siti Aisyah Madiun.

How to cite this article: Nisa EZ, Aulia D, Nasution SS. Effect of supervision on the actions of implementing nurses in the implementation of patient safety at PTPN IV Kebun Laras Hospital, Simalungun Regency. International Journal of Science \& Healthcare Research. 2021; 6(2): 244-250. DOI: https:// doi.org/10.52403/ijshr.20210444 